Research.

\title{
The effect of product quality, price and product availability upon the purchasing decision to buy electricity cable of kabel metal brand in the area of DKI Jakarta
} (Case Study at PT. KMI Wire and Cable Tbk.)

\author{
Supriyatno ${ }^{{ }^{*}}$ and S. Hartoyo ${ }^{2}$ \\ 1*2 Mercubuana University, Jakarta, Indonesia \\ 1*yatnos1207@gmail.com, ${ }^{2}$ harthoyo.s@gmail.com \\ ${ }^{*}$ Corresponding author
}

Received: April 12, 2020; Accepted: May 25, 2020; Published: June 30, 2020

To cite this article: Supriyatno and S. Hartoyo. 2020. The effect of product quality, price and product availability upon the purchasing decision to buy electricity cable of kabel metal brand in the area of DKI Jakarta (Case Study at PT. KMI Wire and Cable Tbk.). The Management Journal of BINANIAGA. 5 (1): 45-58. doi: 10.33062/mjb.v5i01.374

Abstract. This research aims to figure out the effect of Product Quality, Price and Stock Availability upon the Decision to Purchase Cable of Kabelmetal brand in DKI Jakarta. (Case Study at PT KMI Wire and Cable Tbk). Sampling technique of this research is sampling probability using Simple Random Sampling. This research has applied 100 respondents using quantitative descriptive approach and is located in DKI Jakarta. Therefore, data analysis has applied statistical analysis of multiple linear regression test. Data is processed by using SPSS Version 21. Result of analysis using SPSS version 21 indicates that only two of the three hypotheses have affected significantly. Result of the research has identified that Product Quality has affected significantly the Purchasing Decision which is $0.005<0.05$ and Price has affected the Purchasing Decision which is $0.000<0.05$. However, the hypothesis that has not affected the Purchasing decision is Product availability which value is $0.529>$ 0.05 .

Keywords: Product Quality, Price, Product Availability, Purchasing Decision.

\section{INTRODUCTION}

Along with business development recently, it has been providing business opportunity and challenge for the companies that are competing to supply customers requirement. A company should have been able to compete with other companies in order to survive and on the other word, the company should have to be fully aware of the customers requirement and to make them satisfied. Therefore, in the globalization era recently, there are so many producers coming up to sell the same type of the product.

In a house electricity installation, electricity cable is one of vital components having the function to transmit electricity power from PLN to electric tools in a house.

The following table is some price comparison of cable on the online market at tokopedia.com and bukalapak.com identifying reputable shops. Since there are so many cable size, so that, price identification has taken only common cable type which is NYM cable, size of $3 \times 2.5 \mathrm{~mm}^{2}$, as follows: 


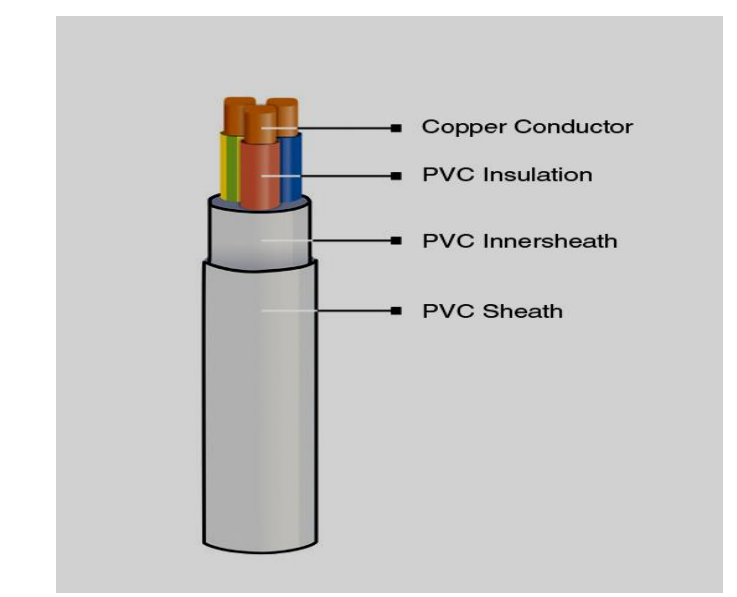

Resource : Sales \& Marketing Data of PT KMI Wire \& Cable Tbk, 2018

Figure 1.

NYM cable type size of $3 \times 2.5 \mathrm{~mm}^{2}$

Table 1.

Price Comparison of NYM cable type size of $3 \times 2.5 \mathrm{~mm}^{2} /$ meter

\begin{tabular}{|c|l|r|r|}
\hline No. & \multicolumn{1}{|c|}{ Brand } & \multicolumn{2}{|c|}{ NYM 3 x 2.5 $\mathbf{~ m}^{\mathbf{2}}$ Cable } \\
\hline & & \multicolumn{1}{c|}{ Tokopedia } & Bukalapak \\
\hline 1 & Voksel & 10,700 & 10,500 \\
\hline 2 & Supreme & 10,560 & 10,500 \\
\hline 3 & Kabelindo & 10,650 & 10,800 \\
\hline 4 & Kabelmetal & 10,900 & 10,800 \\
\hline 5 & Eterna & 10,600 & 10,600 \\
\hline 6 & Jembo & 10,260 & 10,350 \\
\hline
\end{tabular}

Resource: www.tokopedia.com \& www.bukalapak.com. 2018

The table above has shown that the cheapest cable is at Tokopedia which is Eterna of Rp 10.260 / m and the highest one is Kabelmetal of Rp 10.900 / m, it has explained that the customers of Tokopedia application have tended to choose Eterna instead of Kabelmetal which is the highest price. However, in Bukalapak application, it has shown the cheapest price is Jempo which is $\mathrm{Rp} 10.350 / \mathrm{m}$ and the highest ones are Kabelindo and Kabelmetal having the same price of Rp $10.800 / \mathrm{m}$. it has explained that the customers of Bukalapak have tended to pick Jembo instead of Kabelmetal.

\section{LITERATURE REVIEW}

\section{Product Quality}

Referring to Alma (2011) quality is the superiority of related product. But according to the point of view of customers, they have had a specific different range with producers' point of view when they deliver real quality of the product. In general, product according to the producers is a product offered as the result to get the profit related to supply the customers request.

Referring to Kotler (2013) product quality is the capability of a product to show its function, it is covering durability, reliability, on time delivery, ease to operate and to repair the product as well as other attribution of the product.

Supriyatno and S. Hartoyo. The effect of product quality, price and product availability upon the purchasing decision to buy electricity cable of kabel metal brand in 


\section{Price}

Referring to Kotler, (2012) Price is a certain amount required upon a product or service, or, price is a certain amount of the value given by the customer to get the benefit of having or using the product or the service.

According to Tjiptono, (2017:289) price is a monetary unit or other measurement including product or other service) which has been exchanged with the product or service to be the owner or user of it.

Referring to Dharmmesta et al. (2012:147) in sales management, price is a certain amount of money (added with some products) required in order to have total of combination between product and the service.

\section{Product Availabity}

Referring to Handoko (2011:333) inventory is a common term indicating all resources of an organization which are being kept to anticipate the requests fulfilment. Requisition of resources are coming from either internal or external and inventory has covered stock of raw materials, product in process, finished products, excipients or supporting agents and other components which is part of the outcome of marketing products.

Referring to Pranoto (2003:59) indicated that Inventory (stock) management is an activity covering planning, execution and supervision to determine materials required which is meeting the operation requirement to be ready on time and optimum inventory cost reduction.

\section{Purchasing Decision}

Referring to Sulistyari (2012:19) indicated that willingness to buy is defined as buyer probability to purchase the product.

According to Schiffman and Kanuk (2010) defined that willingness to buy is a kind of people attitude upon a product which is suitable to measure their attitude against type of product, service or a certain branded product.

Referring to Kotler \& Keller (2014), willingness to buy is consumer behavior coming up as a response upon an object showing customer's intention to buy.

\section{The Effect of product quality upon Purchasing Decision.}

Referring to Alma (2011), quality is a superiority of the product. Quality according to consumer's perception is having particular scope which is different from producers' perception when they introduce the product with a real quality.

\section{The Effect of price upon Purchasing Decision}

Referring to Kotler, (2012), price is a certain amount to be paid for either a product or a service. Moreover, price is the value given by the customers to get profit of having or using either a product or a service.

\section{The Effect of product availability upon Purchasing Decision.}

Referring to Pranoto (2003:59) stated that inventory/stock management is an activity referring to planning, execution and supervision to decide materials to be required to meet operation requirements which is on time delivery and reduction cost of inventory as much as possible.

\section{$H_{1}$ : Quality of the Product has affected Purchasing Decision.}

Referring to Lilik Kurniawan (2017), stated that quality of the product has affected positively and significantly Purchasing Decision. 
Referring to Selvi Nurjana (2017) stated that quality of the product has affected positively and significantly Purchasing Decision.

Referring to Santoso (2018) stated that quality of the product has affected positively and significantly Purchasing Decision.

\section{$\mathrm{H}_{2}$ : Price has affected Purchasing Decision.}

According to Erwan Mahmudi (2018) stated that price has affected positively and significantly Purchasing Decision.

According to Novita Tiurma (2017) stated that price has affected positively and significantly Purchasing Decision.

According to Ratna Dwi Piaran (2017) stated that price has affected positively and significantly Purchasing Decision.

\section{$\mathrm{H}_{3}$ : Product availability or stock has affected Purchasing Decision.}

Referring to Andrie Purmiantono (2014) stated that product availability has affected positively and significantly Purchasing Decision.

Referring to Kanti Rahayu Utami (2013) stated that product availability/stock has affected positively and significantly Purchasing Decision.

According to Reza Manti Sawirudin (2016) stated that products stock has affected positively and significantly Purchasing Decision.

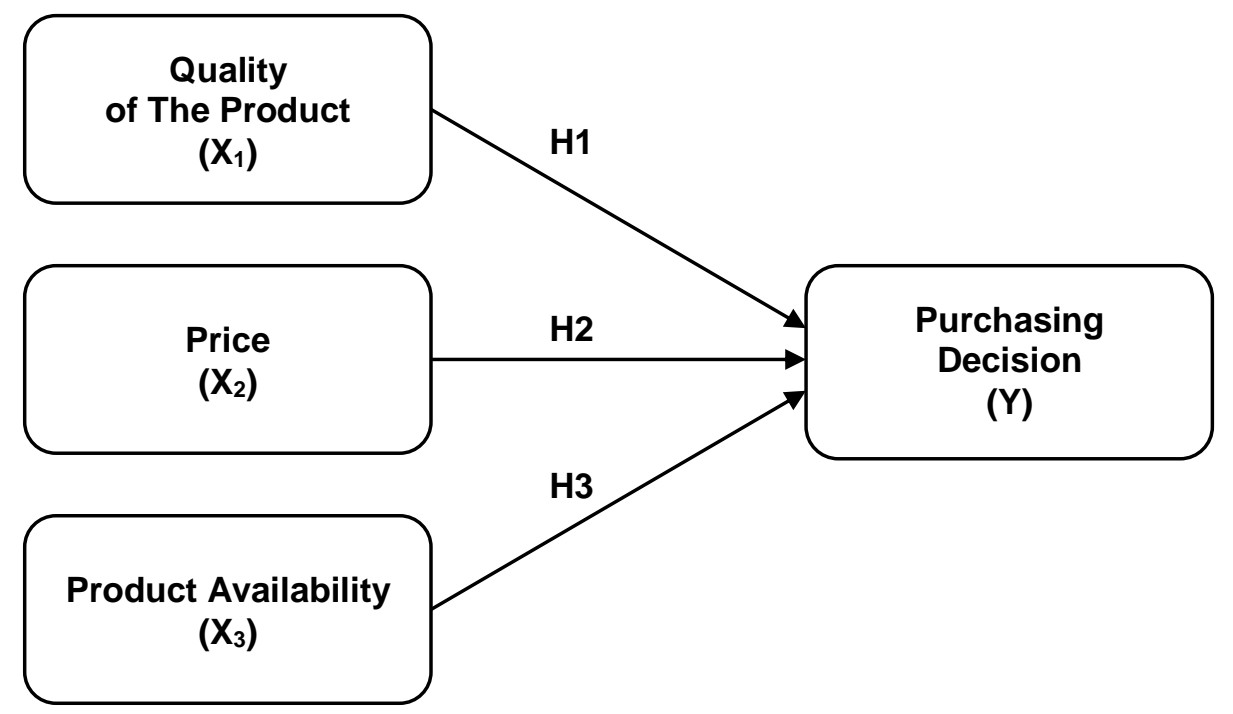

Figure 2.

Conseptual Design

\section{RESEARCH METHOD}

This research has applied conclusive research design which is data resources are primary data and data collection using questionnaires and documentation.

\section{Research Design}

This research has applied causal research (Sugiyono, 2016:93.) This research is considered the highest level comparing to descriptive and comparative one, since it can produce a theory which is enable to describe, predict and control a kind of symptom.

Supriyatno and S. Hartoyo. The effect of product quality, price and product availability upon the purchasing decision to buy electricity cable of kabel metal brand in 
Using this method is complying to the aims of the research which is to figure out the extent to which the effects of product, price and products availability have affected the Purchasing Decision to buy the electrical cable of Kabelmetal brand. In this research, the researcher has applied SPSS program version 21 for windows to process the data of questionnaires.

\section{Location and Time of the Research}

The location of the research had taken place the area at Jl. Raya Bekasi KM 23.1 West Cakung, East Jakarta. And the time of the research had started in November 2018 to December 2018.

\section{Research Variables}

This research has had three independent variables which is Quality of the product, Price and Product availability, and one dependent variable which is the Purchasing Decision.

\section{Population and Sample of the Research}

This research has applied non-probability sampling using census sampling technique. Non-probability sampling is a sampling technique which does not provide the same opportunity for each agent or population member chosen as the sample(Sugiyono, 2016:84) Census sampling is a sampling technique taken when all the population are being used as the samples (Sugiyono, 2016:85).Therefore, the writer has chosen census sampling technique because total of the population are relatively small.

However, research sampling size, according to Roscoe in the book of Research Methods for Business (Sugiyono, 2010:52) is as the following:

1. Acceptable samples size in a research is between 30 up to 500 .

2. If the samples are divided into category (example: women-men, government workerprivate worker, etc.) total of the sample should be at least 30 for each category.

3. If a research is doing analysis using multivariate (correlation or multiple regression), total of the samples should be at least 10 times of the variables being studied. Eq. variables of the research are 5 (independent + dependent), total of the samples $=10$ $x 5=50$

4. For a simple experimental research that is using experiment group and controlled group, total of the samples should be between 10 up to 20 each.

Based on the theories above, the researcher has used 100 persons who are using electrical cable of Kabelmetal brand as total of the samples of this research.

\section{ANALYSIS RESULT OF THE RESEARCH}

\section{Charateristics of Respondents Profile}

Table 2.

Respondents characteristics based on gender, education, age, monthly income, business unit.

\begin{tabular}{|c|c|c|}
\hline Gender & Frequence & Percentage (\%) \\
\hline Man & 53 & 53 \\
\hline Woman & 47 & 47 \\
\hline Total & $\mathbf{1 0 0}$ & $\mathbf{1 0 0}$ \\
\hline Education & Frequence & Percentage (\%) \\
\hline Senior High School/similar & 26 & 26 \\
\hline Diploma ( D3/D4) & 27 & 27 \\
\hline
\end{tabular}

Supriyatno and S. Hartoyo. The effect of product quality, price and product availability upon the purchasing decision to buy electricity cable of kabel metal brand in the area of DKI Jakarta (Case Study at PT. KMI Wire and Cable Tbk.) 
The Management Journal of BINANIAGA Vol. 05, No. 01, June 2020

p-ISSN: 2527-4317, e-ISSN: $2580-149 x$

$6^{\text {th }}$ Accreditation Rating: April 04, 2019 - April 03, 2024

\begin{tabular}{|c|c|c|}
\hline Bachelor degree ( S1) & 46 & 46 \\
\hline Magister (S2) & 1 & 1 \\
\hline Total & 100 & 100 \\
\hline Age & Total & Percentage \\
\hline $21-30$ years old & 11 & 11 \\
\hline $31-40$ years old & 70 & 70 \\
\hline $41-50$ years old & 17 & 17 \\
\hline$\geq 51$ years old & 2 & 2 \\
\hline Total & 100 & 100 \\
\hline Monthly income & Frequence & Percentage \\
\hline 2.5 - 5 millions & 8 & 8 \\
\hline $5-10$ millions & 30 & 30 \\
\hline $10-15$ millions & 26 & 26 \\
\hline$\geq 15$ millions & 36 & 36 \\
\hline Total & 100 & 100 \\
\hline Business Unit & Frequence & Percentage \\
\hline Reseller & 16 & 16 \\
\hline Distributor & 15 & 15 \\
\hline Retail & 11 & 11 \\
\hline $\begin{array}{c}\text { Shops } \\
\text { Contractors }\end{array}$ & $\begin{array}{l}25 \\
33\end{array}$ & $\begin{array}{l}25 \\
33\end{array}$ \\
\hline Total & 100 & 100 \\
\hline
\end{tabular}

Resources: Output SPSS 21

Result of Descriptive Statistics Test

Table 3. Result of Descriptive Statistics Test

\begin{tabular}{|l|c|c|c|}
\hline \multicolumn{1}{|c|}{ Variable } & N & Mean & Std. Deviation \\
\hline Quality of the product & 100 & 3,493 & 0,594 \\
\hline Price & 100 & 3,701 & 0,491 \\
\hline Product availability / stock & 100 & 3,440 & 0,684 \\
\hline Purchasing Decision & 100 & 3,793 & 0,484 \\
\hline
\end{tabular}

Resource: Output SPSS 21

Based on the table 3 above, it has indicated:

1. Mean of counting from the distributors about Quality of the product is 3.493 explaining that in general the respondents agree with the statement mentioned on the questionnaires regarding Quality of the product.

2. Mean of counting from the distributors about Price is 3.701 explaining that in general the respondents agree with the statement mentioned on the questionnaires regarding Price variable.

3. Mean of counting from the distributors about Product availability is 3.440 explaining that in general the respondents agree with the statement mentioned on the questionnaires regarding Product availability / stock.

Supriyatno and S. Hartoyo. The effect of product quality, price and product availability upon the purchasing decision to buy electricity cable of kabel metal brand in the area of DKI Jakarta (Case Study at PT. KMI Wire and Cable Tbk.) 
Result of Validity Test upon variable of Quality of the product.

Table 4, Result of Validity Test upon variable of Quality of the product.

\begin{tabular}{|c|c|c|}
\hline Statement & Pearson Correlation & Description \\
\hline KU1 & 0,611 & Valid \\
\hline KU2 & 0,687 & Valid \\
\hline KU3 & 0,631 & Valid \\
\hline KU4 & 0,724 & Valid \\
\hline KU5 & 0,725 & Valid \\
\hline KU6 & 0,559 & Valid \\
\hline KU7 & 0,735 & Valid \\
\hline KU8 & 0,845 & Valid \\
\hline KU9 & 0,771 & Valid \\
\hline KU10 & 0,513 & Valid \\
\hline KU11 & 0,780 & Valid \\
\hline KU12 & 0,221 & Valid \\
\hline
\end{tabular}

Resource: Output SPSS 21

Based on the Table 4 above, 12 statements of product quality variable are declared valid since the value of Pearson Correlation ( $r$ count) is bigger than variable $r$ table which is (0.1966). Nevertheles all the items of the statement of Product quality variable are valid and can continue to perform the following test.

\section{Result of Validity Test upon Price variable}

Table 5 Result of Validity Test upon Price Variable

\begin{tabular}{|c|c|c|}
\hline Statement & Pearson Correlation & Description \\
\hline HG1 & 0,553 & Valid \\
\hline HG2 & 0,392 & Valid \\
\hline HG3 & 0,545 & Valid \\
\hline HG4 & 0,736 & Valid \\
\hline HG5 & 0,439 & Valid \\
\hline HG6 & 0,747 & Valid \\
\hline HG7 & 0,806 & Valid \\
\hline
\end{tabular}

Resource: Output SPSS 21

Based on Table 5 above, 7 statements of Price variable determined valid since Pearson Correlation ( $r$ count) is bigger than $r$ table $(0.1966)$, therefore, all the items of Price variable are declared valid and can continue to perform the following test.

Result of Validity Test upon Product availability.

Table 6 Result of Validity Test upon Product availability

\begin{tabular}{|c|c|c|}
\hline Statement & Pearson Correlation & Description \\
\hline KE1 & 0,702 & Valid \\
\hline KE2 & 0,751 & Valid \\
\hline KE3 & 0,776 & Valid \\
\hline KE4 & 0,861 & Valid \\
\hline KE5 & 0,862 & Valid \\
\hline
\end{tabular}

Supriyatno and S. Hartoyo. The effect of product quality, price and product availability upon the purchasing decision to buy electricity cable of kabel metal brand in the area of DKI Jakarta (Case Study at PT. KMI Wire and Cable Tbk.) 


\begin{tabular}{|c|c|c|}
\hline Statement & Pearson Correlation & Description \\
\hline KE6 & 0,766 & Valid \\
\hline
\end{tabular}

Resource: Output SPSS 21

Based on Table 6 above, 6 statements of Product availability variable are declared valid, since its Pearson Correlation ( $r$ count) is bigger than $r$ table $(0.1966)$, therefore all the items of the statement regarding Product availability stated on the questionnaires are valid and can continue to perform further test.

\section{Result of Validity Test of the Purchasing Decision.}

Table 7 Result of Validity Test upon the Purchasing Decision.

\begin{tabular}{|c|c|c|}
\hline Statement & Pearson Correlation & Description \\
\hline KP1 & 0,423 & Valid \\
\hline KP2 & 0,688 & Valid \\
\hline KP3 & 0,396 & Valid \\
\hline KP4 & 0,484 & Valid \\
\hline KP5 & 0,722 & Valid \\
\hline KP6 & 0,571 & Valid \\
\hline KP7 & 0,734 & Valid \\
\hline KP8 & 0,516 & Valid \\
\hline KP9 & 0,742 & Valid \\
\hline
\end{tabular}

Resource: Output SPSS 21

Based on Table 7 above, 9 statements of Purchasing Decision variable are valid since its Pearson Correlattion ( $r$ count) is bigger than $r$ table $(0.1966)$, therefore all the items of the statement regarding the Purchasing Decision variable are valid and can continue to perform further test.

\section{Resultt of Reliability Test}

Table 8 Result of Reliability Test

\begin{tabular}{|l|c|c|c|}
\hline \multicolumn{1}{|c|}{ Variable } & Cronbach's Alpha & N of Items & Description \\
\hline Quality of the Product & 0,879 & 12 & Reliable \\
\hline Price & 0,707 & 7 & Reliable \\
\hline Product Availability/Stock & 0,876 & 6 & Reliable \\
\hline Purchasing Decision & 0,771 & 9 & Reliable \\
\hline
\end{tabular}

Resource: Output SPSS 21

Based on Table 8 above, variables of Product quality, product availability and the Purchasing Decision have indicated their Cronbach's Alpha is bigger than 0.60 explaining that all the variable of this research declared reliable. It has explained that the items of the statement being used has reached reliable data.

\section{Result of Classical Assumption Test}

1. Result of Normality Test

Normality test aims to test whether residual variable has distributed normally in the regression model. As indicated that $t$ test had assumed that residual value had been following normal distribution.

Supriyatno and S. Hartoyo. The effect of product quality, price and product availability upon the purchasing decision to buy electricity cable of kabel metal brand in the area of DKI Jakarta (Case Study at PT. KMI Wire and Cable Tbk.) 
Test of Normality Test

Table 9 Result of Normality Test

\begin{tabular}{|c|c|c|}
\hline & & $\begin{array}{c}\text { Unstandardized } \\
\text { Residual }\end{array}$ \\
\hline $\mathrm{N}$ & & 100 \\
\hline & Mean & 0,00000000 \\
\hline Normal Parameters ${ }^{\mathrm{a}, 0}$ & Std. Deviation & 0,31572984 \\
\hline & Absolute & 0,091 \\
\hline Diffarances. & Positive & 0,091 \\
\hline & Negative & $-0,041$ \\
\hline Kolmogorov-Smirnov & & 0,909 \\
\hline Asymp. Sig. (2-tailed) & & 0,381 \\
\hline
\end{tabular}

Resource: Output SPSS 21

Table 9 Result of Reliability test above is to figure out whether the Purchasing Decision has been distributed normally or not, it is indicated on its significance value (Asymp.Sig. 2-tailed). If its sig.value is more than 0.05, it has explained that data distribution is normal. Based on Table 8 above, it has indicated sig of 0.381 explaining that residual data of this research has been distributed normally.

2. Multicolinearity Test Result

Multicolinearity means that inter dependent variables within regression model are having perfect linear correlation or closely perfect correlation. Good regression model should not have had perfect correlation or closely perfect correlation among dependent variables.

\section{Multicoliniearity Test Result}

Table 10. Result of Multicoliniearity Testt

\begin{tabular}{|l|c|c|c|}
\hline \multicolumn{1}{|c|}{ Independent Variables } & Tolerance & VIF & Description \\
\hline Quality of the Product & 0,422 & 2,372 & No Multicolinearity \\
\hline Price & 0,615 & 1,626 & No Multicolinearity \\
\hline Product Availability & 0,412 & 2,429 & No Multicolinearity \\
\hline
\end{tabular}

Resource: Output SPSS 21

Based on Table 10 above, it has indicated that the three independent variables in this research are indicating Tolerance value of more than 0.10 and VIF value less than 10. Nevertheless, multicollinearity has not happened among the independent variables in this research.

\section{Heteroscedasticity Test Result}

According to Wijaya mentioned in Sarjono and Julianita (2013:66) heteroscedasticity indicating that variable variants are not the same for all observation. If the variants of observation of residual from one observation to another observation is constant, it is indicating homocedasticity. 
The Management Journal of BINANIAGA Vol. 05, No. 01, June 2020

p-ISSN: 2527 - 4317, e-ISSN: $2580-149 x$

$6^{\text {th }}$ Accreditation Rating: April 04, 2019 - April 03, 2024

\section{Heteroscedasticity Test Result}

Table 11. Heteroscedasticity Test Result

\begin{tabular}{|l|c|c|}
\hline \multicolumn{1}{|c|}{ Independent variable } & Significance & Description \\
\hline Quality of the product & 0,682 & No Heteroscedasticity \\
\hline Price & 0,873 & No Heteroscedasticity \\
\hline Stock of the product/availability & 0,930 & No Heteroscedasticity \\
\hline
\end{tabular}

Source: Output SPSS 21

Based on the Table 11 above, it has explained that using Spearman's rho correlation method showing that the three independent variables are having significance value (Sig. 2 Tailed) bigger than 0.05 . Since its sig.value $>0.05$ it has indicated that there is not any heteroscedasticity occurred.

\section{Model Compliance Test Result}

1. Result of Determinant Coefficient Test $\left(R^{2}\right)$

$\left(\mathbf{R}^{2}\right)$ Determinant Coefficient Test Result

Table 12 Result of Determinant Coefficient Result $\left(R^{2}\right)$

\begin{tabular}{|c|c|}
\hline R Square & Adjusted R Square \\
\hline 0,576 & 0,563 \\
\hline
\end{tabular}

Source: Output SPSS 21

Based on Table 12 above, Adjusted $R$ Square $\left(R^{2}\right)$ is $0.563=56.3 \%$, indicating that the effect of Quality of the product, Price and Product availability upon the Purchasing Decision is $56.3 \%$ and the remaining of $43.7 \%$ is affected by other variables which are not mentioned on this research such as; location, brand image, service, etc.

2. ANOVA F Test Result

\section{Result of ANOVA F Test}

Table 13. Result of Anova F Test

\begin{tabular}{|c|c|}
\hline F count & Significance \\
\hline 43,500 & 0,000 \\
\hline
\end{tabular}

Source: Output SPSS 21

Based on Table 13 of Result of ANOVA F test, $F_{\text {count }}$ is 43.500 and sig.value of 0.000 . F table is indicated on the statistics table at sig.level of 0.05 and df 1 (total variables -1$)=3$, and df $2(n-k-1)$ or $100-3-1=96$, and $F$ table of 2.70. This result has shown the regression model applied in this research has been complying with and is applicable to perform multiple linear regression analysis and hypotheses test ( $t$ test).

\section{Result of Multiple Linear Regression Analysis Test.}

Multiple Linear Regression Analysis is applied to test simultaneous effects of some independent variables upon a dependent variable which is interval scale (Sarjono and Julianita, 2013:91).

Supriyatno and S. Hartoyo. The effect of product quality, price and product availability upon the purchasing decision to buy electricity cable of kabel metal brand in 
Table 14. Result of Test Analysis of Multiple Linear Regression.

\begin{tabular}{|l|c|c|c|c|c|}
\hline \multirow{2}{*}{ Model } & \multicolumn{2}{|c|}{ Unstandardized Coefficients } & $\begin{array}{c}\text { Standardized } \\
\text { Coefficients }\end{array}$ & \multirow{2}{*}{ T } & \multirow{2}{*}{ Sig. } \\
\cline { 2 - 3 } & $\mathrm{B}$ & Std. Error & Beta & & \\
\hline (Constant) & 0,972 & 0,253 & & 3,845 & 0,000 \\
\hline Quality of the product & 0,241 & 0,083 & 0,295 & 2,884 & 0,005 \\
\hline Price & 0,492 & 0,084 & 0,499 & 5,892 & 0,000 \\
\hline Product availability & 0,046 & 0,073 & 0,065 & 0,632 & 0,529 \\
\hline
\end{tabular}

Source: Output SPSS 21

Based on the table 14 above, it has determined multiple linear regression equation as the following:

$$
\mathrm{KP}=0,972+0,241 \mathrm{KP} 1+0,492 \mathrm{HG}+0,046 \mathrm{KP} 2
$$

1. Constant of +0.972 indicating that if the value of quality of the product, price and product availability variables is happened, then, the value of Purchasing Decision (KP) will be +0.972 .

2. Regression coefficient of product quality variable (KP1) of +0.241 has been indicating that affective commitment has made positive effect upon the Purchasing Decision $(\mathrm{KP})$. It means that the better the quality of the product will increase the Purchasing Decision.

3. Regression coefficient of price variable $(\mathrm{HG})$ of +0.492 has been indicating that it has affected positively the Purchasing Decision. It means that the better the price will increase the Purchasing Decision.

4. Regression coefficient of product availability variable (KP2) of +0.046 has indicated that product availability has affected positively the Purchasing Decision (KP). It has explained that the better the product availability will increase the Purchasing Decision.

\section{Result of Hypotheses Test}

As a matter of fact the Statistics test of $t$ has indicated the extent to which the effect of one independent variable individually can describe dependent variable (Ghozali, 2013:98)

\section{Result of Hypotheses Test}

Table 15. Result of Hypotheses Test

\begin{tabular}{|l|c|c|}
\hline \multicolumn{1}{|c|}{ Independent variables } & t count & Significance \\
\hline Quality of the Product & 2,884 & 0,005 \\
\hline Price & 5,892 & 0,000 \\
\hline Product Availability & 0,632 & 0,529 \\
\hline
\end{tabular}

Source: Output SPSS 21

Based on the table 15 above, it has indicated that:

1. Result of Hypothesis of quality of the product variable which is t count of 2.884 is bigger than t table of $1.984(2.884>1.984)$, and sig.value of 0.005 less than 0.05 $(0.005<0.05)$ has explained that quality of the product has affected significantly the Purchasing Decision. Nevertheless, Hypothesis 1 describing "Quality of the Product has affected positively and significantly the Purchasing Decision" is accepted.

2. Result of hypothesis of price variable which is t count of 5.892 is bigger than t table of $1.984(5.892>1.984)$ and its sig.value of 0.000 is less than $0.05(0.000<0.05)$ has been explaining that price has affected significantly the Purchasing Decision.

Supriyatno and S. Hartoyo. The effect of product quality, price and product availability upon the purchasing decision to buy electricity cable of kabel metal brand in the area of DKI Jakarta (Case Study at PT. KMI Wire and Cable Tbk.) 
Nevertheless, Hypothesis 2 describing "Price has affected positively and significantly the Purchasing Decision" is accepted.

3. Result of hypothesis of Product availability variable which is t count value of 0.632 is less than t table of $1.984(0.632<1.984)$, and its sig.value of 0.529 is bigger than $0.05(0.529>0.05)$ has explained that the product availability has not affected the Purchasing Decision. Nevertheless, Hypothesis 3 describing "Product availability has affected positively and significantly the Purchasing Decision" is rejected.

\section{Description of Result of the Research}

In order to clarify the result which is obtained based on the result of multiple linear regression analysis and hypotheses test, the following subject has described each effect of independent variables which is Quality of the product, Price and Product availability.

\section{The Effect of Quality of the Product Upon the Purchasing Decision.}

The result of this research has shown that quality of product has affected positively and significantly the Purchasing Decision to Buy the electricity cable of Kabelmetal brand. This result is getting along with the previous researches done by:

1. Lilik Kurniawan (2017) declared that quality of the product had affected positively and significantly the Purchasing Decision.

2. Selvi Nurjana (2017) determined that quality of the product had affected positively and significantly the Purchasing Decision.

3. Santoso (2018) indicated that quality of the product had affected significantly the Purchasing Decision.

\section{The Effect of Price upon the Purchasing Decision.}

Result of this research has indicated that price has affected positively and significantly the Purchasing Decision to buy the electricity cable of Kabelmetal brand. This research has been getting along with the previous researches done by:

1. Erwan Mahmudi (2018) declared that price had affected positively and significantly the Purchasing Decision.

2. Novita Tiurma (2017) indicated that price had affected positively and significantly the Purchasing Decision.

3. Ratna Dwi Piaran (2017) described that Price had affected positively and significantly the Purchasing Decision.

\section{The Effect of Quality of the Product upon the Purchasing Decision}

Result of this research has indicated that Product availability has not affected the Purchasing Decision to buy the electricity cable of Kabelmetal brand. This research is not getting along with the previous researches done by:

1. Andrie Purmianto (2014) mentioned that the Product availability had affected positively and significantly the Purchasing Decision.

2. Kanti Rahayu Utami (2013) described that product availability has affected positively and significantly the Purchasing Decision.

3. Reza Manti Sawirudin (2016) indicated that product availability had affected positively and significantly the Purchasing Decision. 


\section{CONCLUSION AND SUGGESTION}

\section{Conclusion}

Referring to the result and description above, the conclusion are as the following:

1. Quality of the Product has affected positively and significantly the Purchasing Decision to buy the electricity cable of Kabelmetal brand. It means that the better the quality of the product of electricity cable of Kabelmetal brand is, the Purchasing Decision to buy the electricity cable of Kabelmetal brand will increase.

2. Price has positively and significantly affected the Purchasing Decision to buy the electricity cable of Kabelmetal brand. It means that the better the price of electricity cable of Kabermetal brand is, the Purchasing Decision to buy the electricity cable of Kabelmetal brand will increase.

3. Product availability has not affected the Purchasing Decision to buy the electricity cable of Kabelmetal brand. It means that the better the condition of product availability of Kabelmetal brand is, the Purchasing Decision to buy the electricity cable of Kabelmetal brand will not increase.

\section{Suggestion}

Based on result of the research, the following suggestions are offered:

1. For the company

Since there are so many competitors, PT KMI Wire and Cable Tbk are expected to improve quality of the product by improving quality test such as raw materials test before performing production process, after production process, so that, the product produced will be able to transfer the electricity power properly.

PT KMI Wire and Cable Tbk, are expected to be able to design the system of pricing which is in compliance with the product benefits and people's purchasing power. The price offered should be affordable for the consumers, so that it will make the consumers pay attention on it and at the end the consumers will decide to buy the product.

2. For next researchers.

Next researcher can expand the research by considering using other variables which are not described on this research, such as, location, promotion, quality of service, brand image, etc. So that, it is expected to get different result of the research. And they could select the respondents correspond to the topic of the research. Therefore, the questions of the statements on the research can be more accurate.

\section{REFERENCE}

Assauri, S. 2017. Manajemen Pemasaran, Edisi Ketujuh, PT Raja Grafindo Persada, Jakarta.

Charlie B. S. \& Arief Bowo P. K. 2015. Jurnal Pengaruh Persepsi Harga dan Promosi Terhadap Keputusan Pembelian Konsumen Produk Enervon-C, Jakarta: Jurnal Ilmiah Manajemen dan Bisnis Volume 1, Nomor 3, November 2015.

Charles Victor, B.S. 2013. Pengaruh Kualitas Produk, Ketersediaan Produk dan Gaya Hidup Terhadap Keputusan Pembelian Produk Lulur Mandi Sumber Ayu di Jakarta, Jakarta: Jurnal MIX, Volume III, No. 2, Juni 2013.

Jembo Cable Company Tbk, PT. 2017. Annual Report 2012 - 2017, Jakarta.

Supriyatno and S. Hartoyo. The effect of product quality, price and product availability upon the purchasing decision to buy electricity cable of kabel metal brand in the area of DKI Jakarta (Case Study at PT. KMI Wire and Cable Tbk.) 
The Management Journal of BINANIAGA Vol. 05, No. 01, June 2020

p-ISSN: 2527-4317, e-ISSN: $2580-149 x$

$6^{\text {th }}$ Accreditation Rating: April 04, 2019 - April 03, 2024

Jessica, J. \& Decky, A. 2014. Pengaruh Kualitas Produk, Harga dan Promosi Terhadap Kepuasan Pelanggan Kartu Prabayar Telkomsel, Jakarta: Jurnal EMBA 1237 Vol.2 No.3 September 2014, Hal. 1237-1245.

Kabelindo Murni Tbk, PT. 2017. Annual Report 2012 - 2017, Jakarta.

KMI Wire and Cable Tbk, PT. 2017. Annual Report 2012 - 2017, Jakarta.

Kotler \& Keller. 2014. Marketing Management, Thirteenth Edition, Pearson Education Inc.

Malhotra, Naresh K. 2005. Marketing Research: An Applied Orientation,Fourth Edition, Prentice \& Hall Inc, New Jersey.

Nurlaela, W.L. 2018. Metodologi Penelitian Terapan, Edisi Kedua, CV Pustaka Amri, Bekasi Barat.

Stephe, P. R. \& Mary, C.. 2009. Manajemen, Edisi Kesepuluh, Erlangga, Jakarta.

Sugiyono. 2016. Metode Penelitian Manajemen.Edisi Kelima, Alfabeta, Bandung.

Supreme Cable Manufacturing and Commerce Tbk, PT. 2017. Annual Report 2012 2017, Jakarta.

Tjiptono, Chandra, G. \& Adriana, D. 2008. Pemasaran Strategik: Mengupas Tuntas Utama Pemasaran Strategik, Branding Strategy, Customer Satisfaction, Strategi Kompetitif \& E-marketing. Andi Offset,Yogyakarta.

Tjiptono, F. 2008. Strategi Pemasaran, Edisi Keempat, Andi Offset, Yogyakarta.

Voksel Electrik, Tbk, PT. 2017. Annual Report 2012 - 2017, Bekasi.

www.topopedia.com

www.bukalapak.com

www.kmi.co.id

www.pln.co.id

Supriyatno and S. Hartoyo. The effect of product quality, price and product availability upon the purchasing decision to buy electricity cable of kabel metal brand in the area of DKI Jakarta (Case Study at PT. KMI Wire and Cable Tbk.) 